\title{
Hetubindutịkā の所作因章
}

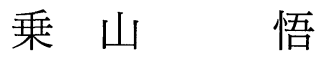

\section{【はじめに】}

ダルマキールティは, Hetubindu（HB, ed. E. Steinkellner）冒頭部分において，隔 絶された事柄に対する認識手段として推論を位置付け，さらに後続する綱領頌の 中で，このような推論を成り立たしめる論証因を三種類に限定した。こうした限 定がなされたのは，三種の論証因についてのみ正しい推理の基盤となる論証因と 所証との不可離の関係が可能であったからである.ダルマキールティは, HB の各 章において，それぞれの論証因に関係する議論を展開してゆくが，当然のごとく， それぞれの議論の背後には，「いかにして不可離の関係が確定されるのか」という 問題が常に意識されている。このことは所作因章でもまったく同様であり，論証 因の形式的分類をなすことに大部分を費やすいわゆる後代の綱要書における所作 因章の内容とは一線を画する。今回の発表では，HB の所作因章に対するアルチャ 夕の註釈 Hetubinduțikā （HBT, ed. S. Sanghavi \& Sh. Jinavijayaji）を検討し, HB の所 作因をめぐる問題に関するアルチャタの理解を考察したい. ただし， HBT の所作 因章に登場する因果関係をめぐる理論そのものは,すでにダルマキールティによっ て考察されていたものに限られており, この種の学説の発展への貢献をアルチャ 夕の記述の中に見出すことは難しい. したがって，本稿の目的は，ダルマキール ティの学説の意義およびその背景となる思想をアルチャタがどのように捉えたか を彼自身の言葉に基づきながら検討し，ダルマキールティの所作因論の理解に資 することにつきる1).

\section{【所作因章の範囲】}

HB 所作因章の註釈を開始するにあたってアルチャタは次のようにのべている : そして以上のように，自性因に打ける同一性の確立の基盤である随伴・排除の確定を説い て, 所作因においてその二つ [随伴・排除] は因果関係の確立の根拠である故に，また直 
接知覚と非知覚を基盤とするそれ [因果関係の確立］は以前にすでに説かれた故に，それ [所作因］に帰属する [自性因とは］別のものも [自性因がそれ自体について迷乱の原因 ではない様に論証因と］別のものごとについて迷乱の原因であることを取り除くために, それ [所作因] について説いて，「別の事物が」（つまり）論証因と別の事物が知られる べき物事である場合,「結果は論証因である」」と［ダルマキールティは］いった．

一方, 別の事物にあらざるものについては自性が論証因であるとすでに語られた．また 何故に, 別の事物について，結果のみが論証因であるのか？という［疑問］に対して答 える‥「逸脱しない故に」と．結果のみが別の事物を逸脱しない，ほかのものは違う，以 前に語られたごとくに，故に別の事物が知られるべきものである場合，結果のみが論証因 であるといわれる。 ${ }^{2)} \cdots$

所作因は，所証と論証因が別であるかという点で自性因と区別されている。そ して，因果関係の確定 ${ }^{3)}$ が，所作因章を説く前提とみなされているのは，自性因 の場合とは異なって所作因によって推論を行う場合, 所証と論証因の因果関係が あらかじめ確定していなければならないからである.HB の所作因章では，確定の 理論は既出のものとされ取り上げられず，決定された因果関係が所作因による推 論の基盤として有効であることの検証が主題となっている ${ }^{4)}$.

\section{【所作因に対する論難】}

HB の 4. 22 節は，いったん確定したとされる因果関係が，あらゆる場面で有効 となりうるのかが主題となっている :

何かが, ある時, あるものにより発生するとしても，そのようであるものがすべて，その ようなものから生み出されるということがどうして確定されるのか？なぜならば，肯定 的・否定的遍充がないだろうから。

これと同じ内容の反論が，PVSVの k. 21 でも取り上げられており，因果関係の 決定の理論への非難としてたびたび繰り返されたことを知りうる。より後代の論 書でも「あるときに A の直後に B が知られることによって他の時も必ず A から B が生じるという限定はしられない」などといった形で同様な非難がとりあげられ ている6

アルチャタはこの非難を二通りに解釈し，それぞれに対して返答を試みている. またどちらの反論解釈においてもその典拠として外教徒のものと思われる偈が引 用されており, 当時の思想界で因果関係の確定の議論がさまざまに批判されてい たことを窥い知りうる ${ }^{7)}$. 
[論難の解釈 1]

ここで, 他者が発言をさしはさむ余地を懸念して［ダルマキールティは］いった.「或 るもの」=煙などが，「ある時に」=ある時間に，「あるもの」=火などから「発生して も」一度火などから発生することが経験された「その様であるもの」（つまり）その種類 に属するけむりなどが「すべて」「そのようなものから発生するものである」（つまり）あ る種類のものから一個のそれ（煙など）が発生することがかつて経験されたところのその 同じ種類のものからの発生を有する（BV）ものである，ということは「いかなる」プラ マーナ「によって」確定されたのか ? ${ }^{81}$

「所作因には因果関係の確立の基盤である随伴と排除がある」といわれている故に。す なわち, 実にもし直接知覚と非知覚とによって, ある煙が火などの複合体の結果であるこ とが了知（avagata）されれば，なぜ，それほどのことによって，それの様な別のもの（別 の煙など）も，それのようなもの（火など）の結果であることが成り立つのか？それに 対しては，それ [因果関係] の基盤である直接知覚と非知覚は作用しない故に，まさにそ れに対して両者（直接知覚と非知覚）が作用するその同じもののみが，それの結果である ことがなければならない. しかしながら, それとは別のものが, どうして［それの推理で あると] 知られようか？[知られるとすれば] そのようなものからそれが発生するであろ うが. ${ }^{9)}$

このように，ある煙という個物が火などの所産であることが目撃されたからといって， なぜ，壶などのそれ（所産）であることが承認されないのであろうか？[論証因とは] 別 である点では［煙と］区別が存在しない故に，そのようであれぱ，過失は何であるのか？ といえば，まさにこのように，プラマーナがないから同様なものから発生することが確定 しないから，そのようでないものからも発生する疑惑がある際，そのようなもの（つま り）煙などは，火などとの随伴と排除が確定しない.ゆえに，なぜ所作因が知らせるもの であろうか？

というのは（hi）, 場所と時間と状態によって限定された, 特定の火を原因とすること が, 直接知覚と非知覚によって確認された一個の煙であるもの, それについてのみ, 随伴 と排除が理解されることはあってはならないからである。それ（一個の煙）は，別の場所 などではあり得ない故に，そうではなくて，そのようなものの普遍的な性質こそが証相で ある故に，そして，それは同様でないものからも発生する疑惑がある際に何故に同様なも のとの随伴あるいは排除があるのか？ ${ }^{10}$

実在物の理解は, 推理によって得がたい, なぜならば, 諸能力は, 状態, 場所, もしく は時間の相違によって様々であるから。 ${ }^{11}$

反論の主旨としては，たとえば火と煙ということで説明すれば，火から煙とい う因果関係の確定がもしなされていたとしても，そのときの特定の火と煙につい 
てだけ随伴と排除が理解されるのであって, そのような煙は別の場所ではありえ ない以上，今問題にしている煙が火と結びついていることは保証されないという ことである。そして場所・時間・状態によって限定された因果関係は推論を成り 立たせるものとしては不十分であり, 場所などが変われば, 結果が同様でない原 因からも発生する疑惑を拭い去りきれない点を指摘したうえで, 「証相としてふさ わしくない」と述べている。この反論の根拠となる学説としてアルチャタはバル トリハリの偈をあげているが，この反論は所作因に基づく推論への疑問として捉 えられていることになる。VPIk. 32 は, 文法学派の立場から, 推論の不確実性を 論じた偈である。

バルトリハリの偈は条件によって実在物の能力がさまざまであることを指摘し ているが, それについてはいわゆる自注の中で詳しく解説されている.「ある状態 で決定された能力やあり方などに関して，人間に，あるいは人間以外に存する別 の状態のもとでは [元の本質とは］異なる本質が経験される.」と述べた上で,「状 態」については「種子や薬草などの外的なものについても状態の違いにより能力 の違いが理解される」といい, 「場所」については,「ヒマラヤの水には非常に冷 たい感触がある。しかし雨雲や火にかけた鍋などにおいては, 同じ形態のものに [ヒマラヤの水よりも] 熱いそれ（触感）が感じられる.」などと述べられる.「時 間」については「夏, 冬などにおいて井戸水などに関して非常に異なった触感が 経験される」というように述べられている。このように記述は極めて具体性の高 いものとなっている. ${ }^{12}$

[アルチャタの答釈]

定説論者はいう。「違う。それから発生しないものは‥」などと．このように考えられる。 この世で, 一度煙等が, 火などの複合体から生ぜられたものとして, 直接知覚と非知覚に よって本性（rūpa）が確定されたとしても，そのようなものは，そのようでないものから も発生することが, 以前に目撃されたもの（yathāparidrișta）とは違うものであるゆえに疑 われる，そこで，この特定の煙が火などの複合体の所産であることがいったん決定された が，それ以外の特定の煙は，一なにしろ諸存在が多様な能力をもつ以上，「そのようでな いものからも生じるのではないか」と懸念されるわけだが，一それ（特定の煙）と比較す れば, そのようなものであるのと同様に, いったん火などの複合体の所産として決定され たそれ（目撃された特定の煙）もそれ以外のもの（別の煙）と比較すれば，そのようなも のにほかならない. そこで，もしそれ以外のそのようなもの（別の煙など）が，そのよう でないもの（火以外のもの）から発生するとすれば, そのとき，そのようなものの自性 は，火などの複合体によって生ぜられたものの自性ではない. ゆえに，目撃された煙に 
とっても，火などの複合体は原因ではないとなるはずだ，そのようなものの自性は，火な ぞの複合体とは異質の原因によって発生された自性であるゆえに ${ }^{13)}$.

そして故に，火などの複合体は原因ではない故に，私によって一度それから発生がみら れた煙，それも発生しない筈だ，Xの原因ではないものから，Xは一度たりとも発生しな い．X爻原因をもたないことになってしまうゆ元に。「それではないものから発生するも の」というが「それ」ということばによって火などという原因という語られようとするこ とが含意される。「それではない」とはそれではないということであり，それと異質であ り，そのようでない，インドラの額などである，それではないものから発生する性質を持 つもの（BV）が「それではないものから発生するもの」ということである，そのような もの，そのような特質を有する煙などの実在物は，「一度も」一回も，「それから」火など から「発生しないゆえに」発生することは矛盾するゆえに，そして，火などの複合体か らそのようなものが発生すれば，「そのようなものの自性にとってそのようなものだけが 原因である」と，かつて発動した直接知覚と非知覚だけから了知される。ゆえにどうして 逸脱の疑惑があろうか？ ${ }^{14}$

しかしアルチャタの返答は, HB におけるダルマキールティの学説を踏襲し, 逐 語的に説明したものである，極めて一般的な表現であり，せっかく反論としてバ ルトリハリの偈を引用してはいるが，それに対応する形での返答にはなっておら ず，いわゆる自注があげたような個々の事例に対していちいち反駁していない. このことは, 両者の間の争点に行き違いがあるというょりは，因果関係の確定を 最重視し，かつ「一度」の経験によっても成り立つとするダルマキールティの立 場を踏襲した上では，このようなバルトリハリの具体的な反論は意味をなさなく なってしまったからであると思われる.

おそらくバルトリハリの偈文の引用は,これが当時大変流布した推論批判であっ たからであろうが，ダルマキールティによって打ち立てられた因果関係に基づく 推論の批判としては的外れなものとして扱われねばならなかった。

\section{[論難の解釈 2]}

あるいはまた, 別様に解説される。この世で直接知覚と非知覚を基盤とする因果関係の 成立が前に説かれた，それの基盤である随伴と排除を明らかにするために，そして，それ は正しくない，すなわち，「あるものが」つまり煙という，火などの複合体の直後に発生 する, 最初のものが,「ある時」つまり最初に発生した時,「あるものから」つまり火など の複合体から，「発生するとしても」生じるとしても，「そのようなものであるすべてが」 最初の刹那において発生するような煙は, 第二などの刹那においてもそのようなものであ る. 直接知覚のみにもとづいて，それは，以前の刹那と異ならざるものとして知られるゅ 
えに.「同様なものから生じる」というのは，X から（つまり）火・薪などの複合体とい う特徵をもつ原因などというようなものから, 煙の瞬間が発生する, Xからの発生を有す る（BV）ということである.「同様なものからの発生を有するというこのことは何ゆえに であろうか」それは煙などからは発生するであろうからである。そして，このようにXと Y から（生じると）目撃されたのであれば，X は別のもの非・Y からも発生することが見 られるゆえに，あらゆる場合を信頼することはないと考える者は言った。「そしてこのよ うに」火ではない煙からも煙が発生する場合に, インドラの額からも，それが発生するこ とに矛盾はないから, 煙には火との随伴と排除は無いというようにもし君が考えれば，と いうのが前主張の疑いである。 ${ }^{15)}$

仏教徒が刹那滅論を主張する場合に，当然付随してくる反論である。これに対 する返答は，第一の反論に対する返答と同じものである ${ }^{16)}$ 。むしろ，幾分議論が かみ合わない傾向があったバルトリハリの偈に対する反論と比較して，こちらの 刹那滅論を前提とした議論の方が，むしろ，ダルマキールテイが想定した反論と して適しているようにも思われる。この「一端発生したものは原因が定まる」と いう議論は，PVSVのk. 34 で述べられたものであったが，それに対するカルナカ ゴーミンの註釈の中に，アルチャタが反論の典拠として引用した所属不明の偈と 同一の偈が引用されていることもそのような理解を裏付けると思われる ${ }^{17)}$.

1）なお HB の分節については, Steinkellner, Dharmakīrti’s Hetubinduh Teil II, 1967 に従 う. 2） HBT 150, 3f 3） 稲見正浩，ダルマキールティにおける「因果関係の決定」，哲 学 39, 1987 などを参照. 4）これは E. Steinkellner 博士の分節に従えば, 4. 21 節と 4. 22 節に相当する。このうち, 4. 21 節については, Pramāṇavārttikasvavṛtti（PVSV, ed. R. Gnoli）のほぼそのままの引用となっており，今回の発表では取り上げない。 5） HB 20*， 2f 6）稲見正浩, 仏教論理学派の因果関係の決定方法について一本当に因果関係は決定で きるのか? - 印度学仏教学研究 47-1，1998, p. 151 参照. 7） アルチャタが反論を二 種類に解釈する点については，E. Steinkellner [1967] の訳注ですでに指摘されている.

8) HBT 153, 16f. 9) HBT 153, 2lf. 10) HBT 153, 27f 11) HBT 154, 10f : avasthādeṣakālānām bhedād bhinnāsu śaktiṣu bhāvānām anumānena pratītir atidurlabhā // (Vakyapadīya （VP, ed. K. A. S. Iyer）Ik. 32 に基づく引用） 12） VP Vṛtti 88, 7f 13） HBT 154, 12f.
14) HBT 154, 23f.
15) HBT 155, 9f.
16) HBT $155,28 \mathrm{f}$.
17) $\operatorname{HBT} 155,24 \mathrm{f}=$

Pramāṇavārttikasvavṛttițīā (PVSVT) 101, 8f

〈キーワード〉 Hetubinduțīkāa, アルチャタ, 所作因 